\title{
The buffer value of groundwater when well yield is limited
}

\author{
T. Foster ${ }^{\mathrm{a}, \mathrm{b}, *}$, N. Brozović ${ }^{\mathrm{b}}$, C. Speir ${ }^{\mathrm{c}}$ \\ ${ }^{a}$ School of Mechanical, Aerospace ES Civil Engineering, University of Manchester, \\ Manchester, United Kingdom \\ ${ }^{b}$ Robert B. Daugherty Water for Food Global Institute, University of Nebraska, Lincoln, \\ Nebraska, United States \\ ${ }^{c}$ National Oceanic and Atmospheric Association (NOAA), Southwest Fisheries Science \\ Center, Santa Cruz, California, United States
}

\begin{abstract}
A large proportion of the total value of groundwater in conjunctive use systems is associated with the ability to smooth out shortfalls in surface water supply during droughts. Previous research has argued that aquifer depletion in these regions will impact farmers negatively by reducing the available stock of groundwater to buffer production in future periods, and also by increasing the costs of groundwater extraction. However, existing studies have not considered how depletion may impact the productivity of groundwater stocks in conjunctive use systems through reductions in well yields. In this work, we develop a hydroeconomic modeling framework to quantify the effects of changes in well yields on the buffer value of groundwater, and apply this model to an illustrative case study of tomato production in California's Central Valley. Our findings demonstrate that farmers with low well yields are forced to forgo significant production and profits because instantaneous groundwater supply is insufficient to buffer surface water shortfalls in drought years. Negative economic impacts of low well yields are an increasing function of surface water variability, and are also greatest for farmers operating less efficient irrigation systems. These results indicate that impacts of well yield reductions on the productivity of groundwater are an
\end{abstract}

\footnotetext{
* Corresponding author

Email address: timothy.foster@manchester.ac.uk (T. Foster)
}

Preprint submitted to Journal of Hydrology

February 17, 2017

(C) 2017. This manuscript version is made available under the Elsevier user license http://www.elsevier.com/open-access/userlicense/1.0/ 
important economic impact of aquifer depletion, and that failure to consider this feedback may lead to significant errors in estimates of the value of groundwater management in conjunctive use systems.

Keywords:

Conjunctive use, Irrigation, Groundwater depletion, Well yield, Buffer value

\section{Introduction}

Conjunctive use of surface water and groundwater is a common practice in many irrigated agricultural regions worldwide, such as California, India, and Spain (Foster and van Steenbergen, 2011, Singh, 2014, Scanlon et al., 2016). Groundwater plays two important roles in these systems. Firstly, groundwater increases total water supply for both agriculture and other sectors. Secondly, it increases supply reliability by providing a stable buffer against uncertain surface water availability (rainfall and/or flows in rivers or canals) caused by climate variability and irrigation system management.

Extensive research has been conducted by both economists and engineers over recent decades to quantify the buffer value of groundwater (Tsur, 1990 Tsur and Graham-Tomasi, 1991, Provencher and Burt, 1994; Knapp and Olson 1995: Tsur, 1997, Ranganathan and Palanisami, 2004, Pulido-Velázquez et al. 2006, Marques et al. 2009: Palanisami et al., 2012). Universally, this work has shown that a significant proportion of the total economic value of groundwater in a conjunctive use setting is related to the ability of groundwater stocks to buffer production against the risks posed by stochastic surface water supplies (Gemma and Tsur, 2007: Tsur, 2015). Additionally, a related body of literature has also demonstrated that groundwater stocks may also have large value as a means of adapting to sudden events or shocks that disrupt surface water supplies, such as natural disasters (Reichard et al. 2010) or droughts (de Frutos Cachorro et al. 2014).

The majority of existing research that has evaluated the stabilization or buffer value of groundwater has considered situations where only surface water 
supply is constrained. In many regions worldwide, however, groundwater stocks are declining rapidly as a result of long-term rates of abstraction that far outstrip natural recharge (Aeschbach-Hertig and Gleeson, 2012; Richey et al., 2015). Aquifer depletion is also likely to be exacerbated further in the future due to increased demands on both groundwater and surface water from population growth and climate change (Taylor et al., 2013, Elliott et al., 2014; Schewe et al. 2014), coupled with growing needs to limit surface water abstractions to protect critically endangered freshwater ecosystems and species Grantham et al., 2014, Grantham and Viers, 2014).

An important consequence of groundwater depletion is the reduction in well yields, which occur as aquifer saturated thickness is reduced and wells become unable to support high-capacity pumping for irrigation (Hecox et al., 2002). Globally, well yield reductions are a commonly cited consequence of aquifer depletion in areas of intensive irrigated agriculture (OECD, 2015). There is significant anecdotal evidence that drawdown in Californias Central Valley over recent decades (Famiglietti et al. 2011, Scanlon et al., 2012), which has increased rapidly during the recent period of severe drought (Faunt et al., 2016), has led to reductions in the yields of irrigation wells and, in some cases, even complete well failure due to the aquifer water levels falling below the base of the well intake screens (Howitt et al., 2014, 2015, Medellín-Azuara et al., 2015, Ritchel 2015: Veshkin, 2015). Lower well yields constrain both total and instantaneous groundwater pumping capacity, and, therefore, may have important implications for the ability to use groundwater as a buffer against variable surface water flows and for the value of groundwater resources. Previous research has demonstrated that low well yields greatly reduce the resilience of groundwater-fed irrigation to drought, and constrain significantly the amount of land that a farmer can irrigate profitably (Foster et al., 2014, 2015a b). However, this research has assumed that groundwater is the sole water supply source, and, consequently, has not considered the implications for farm profits and production risk of interactions between groundwater well yields and stochastic surface water availability.

In this study, we add to the literature on conjunctive use irrigation systems 
by exploring how changes in well yields influence farmers capacity to use groundwater as a reliable buffer against stochastic surface water flows. We adapt an existing hydro-economic modeling approach (Foster et al., 2014, 2015a) to estimate farmers' optimal irrigation decision-making and profits as a function of stochastic surface water supply, well yield, and climate. Through an example application to irrigated tomato production in California, we demonstrate that the economic productivity of groundwater stocks is a decreasing, non-linear function of well yield. Our findings highlight that well yield reductions are an important economic impact of aquifer depletion, which have not been considered in previous studies of conjunctive use systems. The ability to limit effectively future reductions in well yields therefore is an important factor that should be accounted for when evaluating policies to manage groundwater use in conjunctive use systems, in particular as surface water supplies become increasingly constrained and uncertain due to climate change, population growth, and growing environmental demands for water.

\section{Methods}

In this section, we describe the modeling approach used to estimate the joint effects of well yields and stochastic surface water supplies on farm water use and profits. The numerical approach used in this study is adapted from the methodology developed previously by Foster et al. (2014, 2015a), and has two main components: (1) Simulation of crop yield and irrigation water use for different levels of surface water and groundwater supply; (2) Estimation of economically optimal irrigation decisions and farm profits for variable states of a groundwater system. In the following sections, these two steps are described in turn, followed by a discussion of an example application of the model to irrigated tomato production in California's Central Valley.

\subsection{Simulation of crop yields and irrigation requirements}

To estimate crop yields and irrigation water use for different surface water allocations and groundwater pumping capacities, we use a biophysical crop sim- 
ulation model called AquaCrop-OS (Foster et al., 2017). AquaCrop-OS is a free, open-source version of AquaCrop, a crop water productivity model developed by the Food and Agriculture Organization of the United Nations (FAO) (Steduto et al. 2009). The model simulates on a daily time step dynamic changes in crop growth and soil moisture at the field-level. Importantly, the model represents explicitly the effects of a range of environmental stressors, most notably water and temperature, on crop growth processes, making it ideally suited for assessments of crop production in water-constrained regions.

We run AquaCrop-OS iteratively to estimate irrigated crop yields and water use (surface and groundwater) for different possible surface water and groundwater supply constraints. Surface water supply is expressed in terms of the total depth of water available to the farmer over the growing season, and our model setup makes the assumption that farmers will use surface water preferentially to groundwater until either the full surface water allocation is used or the end of the growing season is reached. We justify this assumption based on the fact that surface water is typically significantly cheaper than groundwater (Section 2.2 describes how our model accounts for different costs of surface water and groundwater), and also because delaying use of surface water may result in that water being diverted by other users especially in years when available resources are over-allocated (further discussion of this assumption is provided in Section 4.2. We assume no seasonal limit on groundwater availability, reflecting the fact that in many regions worldwide there currently are no binding limits imposed on agricultural groundwater pumping ( OECD, 2015). Instead, the groundwater supply constraint is expressed as a maximum daily irrigation application rate. The instantaneous groundwater supply constraint is dependent on well yield and irrigated area, which together limit the maximum depth of water that can be applied on any day in AquaCrop-OS. This constraint is important as low instantaneous application rates may be insufficient to meet peak crop water requirements during sensitive growth periods, leading to the build up of soil moisture deficits and reductions in crop yields in particular when surface water supply is exhausted early in the growing season (Foster et al., 2014). 
Decisions about irrigation use in AquaCrop-OS depend on the rules that are specified for intraseasonal irrigation scheduling. We assume that farmers' intraseasonal scheduling heuristics can be characterized by the selection of a soil moisture target strategy (Foster et al. 2014). The soil moisture target strategy represents the proportional soil moisture level at which irrigation is initiated during the four main crop growth stages considered by AquaCrop-OS: (1) Initial stage; (2) Crop development stage; (3) Mid-season stage; (4) Lateseason stage. The soil moisture target is allowed to vary between these growth stages, reflecting the differing sensitivity of crop growth processes to water stress at different points throughout the growing season. In each stage, the lower the soil moisture target, the more the root zone soil profile is allowed to dry out between irrigation events. Choosing a lower soil moisture target therefore will enable limited surface water supplies to last longer in to a growing season. However, if large soil moisture deficits are allowed to build up then water stress may constrain crop growth processes, resulting in reductions in yield at the end of the season, or, in extreme cases, even complete crop failure.

Simulations are performed iteratively for each possible combination of intraseasonal soil moisture target strategy, surface water and groundwater supply constraints. The resulting outputs are three $\mathrm{M} \times \mathrm{S} \times \mathrm{G}$ matrices, describing simulated (1) crop yield; (2) surface water use; and (3) groundwater use; where $\mathrm{M}$ is the number of soil moisture target strategies, $\mathrm{S}$ is the number of surface water allocations, and $G$ is the number of groundwater supply constraints. Note that the previous methodology developed by Foster et al. (2014, 2015a) also considers the effects on crop yields and irrigation use of interannual variability in weather variables (precipitation, temperature, and reference evapotranspiration), which are inputs to AquaCrop-OS simulations. However, for the purposes of this study we focus on weather conditions for an individual average year, as will be discussed in Section 2.3 . 


$$
\begin{gathered}
{\left[A^{*}, S^{*}, \Pi^{*}\right]=\max _{\{A, S\}} \Pi_{A, S}} \\
\Pi_{A, S=}\left[Y\left(S, q_{s w}, q_{g w}\right) \cdot\left(p_{c}-c_{h}\right)-c_{f i}-X_{s w}\left(S, q_{s w}\right) \cdot c_{w_{s w}}\right. \\
\left.-X_{g w}\left(S, q_{g w}\right) \cdot c_{w_{g w}}\right] \cdot A-\left[c_{f} \cdot A_{\max }\right] \\
+\left[\left(R_{d}-c_{f d}\right) \cdot\left(A_{\max }-A\right)\right]
\end{gathered}
$$

Subject to:

$$
\begin{aligned}
& A \leq A_{\max } \\
& q_{s w}=\frac{Q_{s w}}{A} \\
& q_{g w}=\frac{Q_{g w}}{A}
\end{aligned}
$$

\subsection{Economic optimization}

We use the crop yield and irrigation data generated by AquaCrop-OS to determine farmers' private economically optimal irrigation decision-making and profits given stochastic surface water supply and available well yield. Our economic model assumes that the farmer's irrigation decision has two components: (1) an extensive margin choice of how much land to plant with irrigated crops; and (2) an intensive margin decision of the soil moisture target strategy to follow during the growing season. For a given surface water allocation and well yield, the optimal joint irrigation decision is determined by solving Equations 1,2 below.$$
\text { Subject to: }
$$

Where $A^{*}, S^{*}$, and $\Pi^{*}$ are the optimal irrigated area (ha), soil moisture target strategy, and maximized profits, respectively, $\Pi$ is the profit $(\$), Y$ is irrigated crop yield (tonne ha ${ }^{-1}$ ), $X$ is seasonal irrigation $(\mathrm{mm}), S$ is the soil moisture target strategy, $A$ is irrigated area (ha), $A_{\max }$ is the total field area (ha), $p_{c}$ is the crop price $\left(\$\right.$ tonn $\left.^{-1}\right), c_{h}$ is the crop harvesting cost $\left(\$\right.$ tonne $\left.^{-1}\right), c_{f}$ is the fixed production cost per unit area $\left(\$ \mathrm{ha}^{-1}\right), c_{f i}$ is the fixed production cost per 
unit irrigated area $\left(\$ \mathrm{ha}^{-1}\right), c_{w}$ is the cost of irrigation $\left(\$\right.$ ha- $\left.\mathrm{mm}^{-1}\right), R_{d}$ is a fixed revenue from dryland crop production on the non-irrigated land area $(\$$ $\left.\mathrm{ha}^{-1}\right), c_{f d}$ is the fixed production cost per unit non-irrigated area $\left(\$ \mathrm{ha}^{-1}\right), Q$ is the volumetric water supply constraint (ha-mm $\mathrm{yr}^{-1}$ or day ${ }^{-1}$ ), and $q$ is the per-area water supply constraint $\left(\mathrm{mm} \mathrm{yr}^{-1}\right.$ or day $\left.{ }^{-1}\right)$. Subscripts $s w$ and $g w$ denote surface water and groundwater, respectively.

A number of important features in Equations 1 and 2 warrant further discussion. First, the farmer may adjust per-area surface water and groundwater supply by changing the number of irrigated acres planted at the start of the growing season. Land that is not irrigated will still generate revenue, but at a significantly lower rate due to the reduced returns from dryland relative irrigated crop production. Farmers with less secure surface water supplies and/or low well yields therefore must make trade-offs between maximizing potential irrigated production areas, and ensuring that adequate soil moisture levels can be maintained during the season to avoid crop yield losses or failure. Additionally, extensive margin decisions will be further affected by the fact that some fixed costs, $c_{f}$, are payable on the full field area irrespective of whether all available land is irrigated, for example if an advanced irrigation system has been installed on the full field. Finally, the model also makes the assumption that the farmer knows with certainty when making planting decisions what level of surface water allocation they will receive. This is realistic in most conjunctive use systems, where surface water flows typically are controlled by reservoir systems, and farmers are informed before the start of the growing season how much water they should receive. For example, in our study area of California, the majority of farmers receive surface water through centrally-operated reservoirs and canals, such as the Central Valley Project and State Water Project. In these systems, water allocations are announced before planting based on observed snowpack and reservoir levels, and, historically, it is very rare for deliveries to be reduced once the growing season has begun (U.S. Bureau of Reclamation, 2016). However, in situations where this assumption does not hold, the model could be adapted easily by specifying $Q_{s w}$ as an expectation of the surface water 
allocation for the upcoming season (this will explore further in Section 2.3).

Equation 1 is solved repeatedly by drawing values of $Q_{s w}$ at random from a specified distribution, holding $Q_{g w}$ fixed. We then take the mean of the maximized profits across all surface water draws to obtain an expected value of profits as a function of $Q_{g w}, \mathbb{E}\left[\Pi\left(Q_{g w}\right)\right]$. Using this estimate, the total value added by access to groundwater, $V\left(Q_{g w}\right)$, is then calculated as the difference between $\mathbb{E}\left[\Pi\left(Q_{g w}\right)\right]$, and the expectation of profits with no access to groundwater (i.e. when $\left.Q_{g w}=0\right)$ (Equation 3).

$$
V\left(Q_{g w}\right)=\mathbb{E}\left[\Pi\left(Q_{g w}\right)\right]-\mathbb{E}[\Pi(0)]
$$

We can also calculate the total loss in value from reducing well yield to a given level, $L\left(Q_{g w}\right)$, by calculating the difference between $\mathbb{E}\left[\Pi\left(Q_{g w}\right)\right]$, and the expectation of profits with unconstrained groundwater supply $\left(Q_{g w}^{*}\right)$ (i.e. unlimited well yield, which is characteristic of assumptions in previous conjunctive use models) as shown in Equation 4.

$$
L\left(Q_{g w}\right)=\mathbb{E}\left[\Pi\left(Q_{g w}^{*}\right)\right]-\mathbb{E}\left[\Pi\left(Q_{g w}\right)\right]
$$

\subsection{Example application}

We apply our model to a case study of irrigated tomato production in California's Central Valley. Tomato production is a significant component of the agricultural economy in California, with the state producing over $90 \%$ of U.S. processing tomatoes and $35 \%$ of total global production (Hartz et al., 2008). Tomato producers are heavily dependent on reliable water supplies for irrigation, as California's Mediterranean style climate means that precipitation during the growing season is minimal. However, the reliability of surface water supplies is threatened by a combination of growing agricultural, urban, and environmental demands, coupled with reductions in surface runoff due to enhanced drought risk and climate change (Mehta et al. 2013, Seager et al. 2013). Many farmers, therefore, increasingly rely on groundwater as an additional source of water supply (Faunt et al. 2009), which can be used to both buffer surface water deficits 
and increase total farm water availability. However, decades of groundwater abstraction in excess of natural recharge have led to widespread declines in water tables across the Central Valley Aquifer (Famiglietti et al., 2011; Scanlon et al., 2012), with resultant reductions in well pumping capacities threatening the future viability of the aquifer as a buffer against stochastic surface water deliveries.

We parameterize AquaCrop-OS using representative weather, soil, and crop data for irrigated tomato production in California. Daily weather time series (precipitation, maximum and minimum temperature, and reference evapotranspiration) required to run AquaCrop-OS are obtained from the California Irrigation Management Information Systems (CIMIS) weather station at Davis for the year 2003 (data available at: http://www.cimis.water.ca.gov), which represents a year with approximately average growing season (May - August) precipitation $(25 \mathrm{~mm})$ and reference evapotranspiration $(800 \mathrm{~mm})$. Effects of inter-annual weather variability are not considered, as both precipitation (0 - 79 $\mathrm{mm}$ ) and reference evapotranspiration (691 - $859 \mathrm{~mm}$ ) show relatively limited variability across the 30 year record at Davis. Soil type in AquaCrop-OS is assumed to be a loamy soil, with the initial water content in the soil profile at planting (May 1) uniformly equal to $70 \%$ of total available water (i.e. water storage between field capacity and permanent wilting point). This value was obtained by running AquaCrop-OS continuously for a period of 30 years (19862015) at Davis, and taking the average initial soil moisture condition across all years. Finally, we assume the default values for crop parameters describing tomato growth in AquaCrop-OS (Raes et al., 2016). This choice is justified by previous research, which has shown that AquaCrop simulates accurately tomato yield response to water in climatically and agronomically similar Mediterranean environments (Rinaldi et al., 2011; Katerji et al., 2013, Linker et al., 2016). Furthermore, average irrigated tomato yields simulated by AquaCrop-OS (126 tonnes $\mathrm{ha}^{-1}$ ) correspond closely to recent reported yields in California (121 tonnes $\mathrm{ha}^{-1}$ ) (data available at: https://www.nass.usda.gov/Quick_Stats).

We perform simulations using AquaCrop-OS, as described in Section 2.1, for 
potential combinations of per-area surface water and groundwater supply, and a range of intraseasonal soil moisture target strategies. Surface water supply constraints are varied from 0 to $900 \mathrm{~mm} \mathrm{ha}^{-1}$ year $^{-1}$ in increments of $25 \mathrm{~mm}$ $\mathrm{yr}^{-1}$, and groundwater supply constraints range from 0 to $20 \mathrm{~mm} \mathrm{ha}^{-1}$ day $^{-1}$ in increments of $0.5 \mathrm{~mm} \mathrm{ha}^{-1} \mathrm{day}^{-1}$. The soil moisture target in each of the four main crop growth stages is varied from $30 \%$ to $90 \%$ in increments of $2.5 \%$, and we ignore irrigation strategies outside this range as these strategies would result in either wasteful over-irrigation or high risks of crop failure. We repeat simulations for the two most common irrigation methods used for tomato production in California: (1) furrow irrigation; and (2) sub-surface drip irrigation. An important difference between these techniques is the efficiency with which irrigation is applied, defined here as the proportion of applied water that reaches the crop root zone. AquaCrop-OS accounts directly for two factors influencing irrigation efficiency, namely deep percolation of applied water below the root zone and evaporation of water from soil surface layers (Steduto et al., 2009). The latter is affected by the proportion of the soil surface that is wetted by irrigation (the higher the percentage, the more applied water may be lost to non-beneficial soil evaporation), which we set equal to $0 \%$ for sub-surface drip and $60 \%$ for furrow following guidelines given in Raes et al. (2016). AquaCrop-OS, however, does not represent directly other significant factors affecting irrigation inefficiency, such as surface runoff and evaporation of flowing water. For sub-surface drip systems, these losses will be negligible as water is applied directly to the crop root zone. However, for furrow systems, losses may be large, and, therefore, we assume that $20 \%$ of any applied irrigation does not enter the soil profile consistent with typical losses observed in California (Bali et al. 2001, Arnold et al. 2014).

Solving the economic optimization (Section 2.2) requires a number of economic parameters to be defined (Table 1). Tomato crop price is defined according to average tomato prices received by producers in California over the period 2011-2015 (data available at: https : //www .nass . usda.gov/Quick_Stats). Harvest and fixed costs for irrigated tomato production are taken from recent crop 
budgets developed by University of California, Davis (Miyao et al. 2014a b). For sub-surface drip irrigation an additional fixed cost is also estimated per unit of field area (irrespective of whether that land is irrigated or not), to account for costs of installing and maintaining the drip irrigation system. Revenue and fixed costs for dryland production on the non-irrigated portion of the field are assumed to be equal to typical values for dryland oat hay production, a common rotation crop for tomato producers in California, as reported in recent crop budgets (Long et al., 2012). Surface water is assumed to be cheaper than groundwater, reflecting the fact that surface water rates in California, such as for supply from the Central Valley Project, are subsidized heavily, whereas farmers must pay the full energy cost of pumping groundwater from tens or hundreds of meters below the land surface. Finally, we assume that the maximum field area is 65 ha, and that the farmer can adjust irrigated acreage in increments of 0.5 ha.

Table 1: Economic model parameters

\begin{tabular}{ll}
\hline Parameter & Cost \\
\hline Crop price $\left(\$\right.$ tonne $\left.^{-1}\right)$ & 90 \\
Harvest cost $\left(\$\right.$ tonne $\left.^{-1}\right)$ & 10 \\
Dryland revenue $\left(\$\right.$ ha $\left.^{-1}\right)$ & 926.7 \\
Fixed cost (dryland area) $\left(\$\right.$ ha $\left.^{-1}\right)$ & 840.2 \\
Fixed cost (irrigated area) $\left(\$\right.$ ha $\left.^{-1}\right)$ & 4942 (Furrow) 4386 (Drip) \\
Fixed cost (field) $\left(\$\right.$ ha $\left.{ }^{-1}\right)$ & 0 (Furrow) 519 (Drip) \\
Surface water cost $\left(\$\right.$ ha-mm $\left.\mathrm{mm}^{-1}\right)$ & 0.02 \\
Groundwater cost $\left(\$\right.$ ha- $\left.\mathrm{mm}^{-1}\right)$ & 0.04 \\
\hline
\end{tabular}

Following the methodology described in Section 2.2, we estimate the value of groundwater for tomato production as a function of well yield for three alternative surface water distributions and the two irrigation methods (furrow and sub-surface drip) described above. Surface water deliveries are expressed as percentages of full deliveries, defined as the amount of surface water needed 
to meet full crop water requirements on the maximum field area $(58,500$ ha-mm $\left.\mathrm{yr}^{-1}\right)$. All three surface water distributions are uniform, with an upper bound of $100 \%$ delivery. However, the lower bound differs between each distribution to reflect varying levels of surface water supply variability (Table 2). For each irrigation method (i.e. furrow or sub-surface drip), the economic model of farmer irrigation decision-making is solved for 1000 random draws from each specific surface water distribution. Comparison of optimization outputs provides valuable insights about how the value of groundwater is affected by interactions between well yields, irrigation system efficiency, and the level of variability in surface water deliveries faced by the farmer.

Table 2: Properties of surface water distributions. Names of each distribution in the first column (low, moderate, and high) reflect the degree of surface water variability

\begin{tabular}{llll}
\hline Distribution & Lower bound (\%) & Upper bound (\%) & Mean (\%) \\
\hline Low & 80 & 100 & 90 \\
Moderate & 40 & 100 & 70 \\
High & 0 & 100 & 50 \\
\hline
\end{tabular}

Implicit to the analyses described above is the assumption that the farmer knows with certainty what surface water allocation they will receive at the time planting decisions are made in each year. As discussed in Section 2.2 this is a reasonable assumption in most of California where a large proportion of farmers receive water through engineered, centrally-controlled systems of reservoirs and canals. Nonetheless, water managers in the region, and indeed in other similar conjunctive use systems worldwide, do have the authority to reduce surface water deliveries once the growing season has begun, in particular to farmers with junior surface water rights in over-allocated basins. It is therefore an interesting exercise to explore to what extent uncertainty about surface water deliveries at the time of planting affects the impacts of low well yields on crop production risk and profits in conjunctive use systems. In order to answer this question, we repeat the analyses described above, but now assuming that 
irrigation decisions are made on the basis of an expected surface water delivery (i.e. $Q_{s w}=E\left(Q_{s w}\right)$ in Equation 2, where the expectation is equal to the mean surface water delivery for a given distribution). Actual profits subsequently are calculated by re-solving Equation 2, given these irrigation decisions and actual surface water deliveries. Profits under uncertain surface water supply finally are compared with those obtained when surface water deliveries are known with certainty each year, providing an indication of the additional costs associated witg reduced well yields when the farmer has limited knowledge of how much surface water supply to expect at the time planting decisions are made.

\section{Results}

\subsection{Well yield impacts on groundwater value}

We begin by analysing the effects of well yield on the value of groundwater for furrow irrigated tomato production under the moderate variability surface water distribution detailed in Table 2.

Figure 1 shows changes in the optimal irrigated area and crop yield as a function of well yield, and demonstrates that the relationship between tomato production and well yields is non-monotonic. When the farmer has no access to groundwater (i.e. when well yield is set equal to zero), the mean optimal irrigated area and crop yield are equal to 48.5 ha and 91.8 tonne ha $^{-1}$, respectively, with the remainder of the field area cultivated with dryland oat hay. There is also large interannual variability in tomato production, caused by the stochastic fluctuations in surface water deliveries. Increasing well yield raises gradually the mean level of tomato production (both in terms of area irrigated and per-area crop yields), and reduces variability in irrigated crop production from year to year. However, a large well yield $\left(5350 \mathrm{~m}^{3}\right.$ day $^{-1}$ or greater, 980 gpm and above) is required for groundwater supply to buffer production fully against surface water variability. This result reflects the fact that tomatoes are sensitive to water deficits during the growing season, which occur when surface 


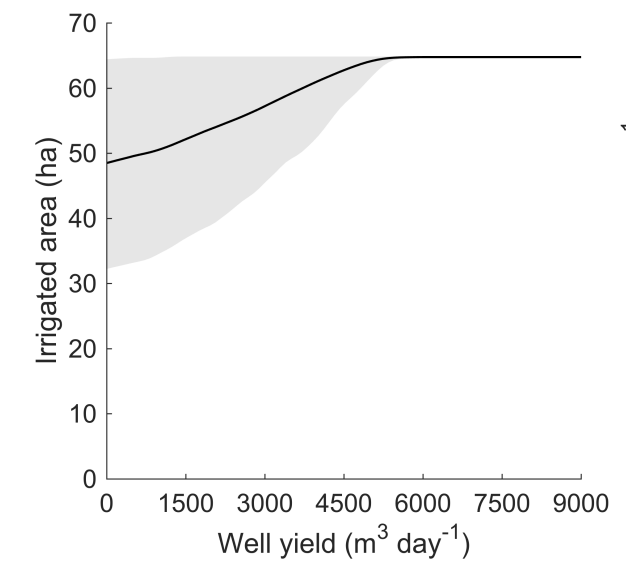
demands.

water supply is limited and well yield is insufficient to satisfy peak crop water

Figure 1: Optimal tomato irrigated area (left) and yields (right) as a function of well yield $\left(\mathrm{m}^{3} \mathrm{day}^{-1}\right)$ and stochastic surface water supply. In each plot, the solid black line shows the mean response and the grey shaded area represents the bounds of the $10-90^{\text {th }}$ percentiles from the 1000 random draws. Tomatoes are assumed to be furrow irrigated, and surface water deliveries are drawn from the moderate distribution given in Table 2 Note that $1 \mathrm{~m}^{3} \mathrm{day}^{-1}$ is equivalent to $0.183 \mathrm{gpm}$.

The effects of well yield on farmers' irrigation decisions and tomato production output are reflected in the optimal farm profits predicted by our model. Figure 2 a shows that profits exhibit a similar non-linear response to well yield, with expected profits peaking at around $\$ 325,750$ for well yields above $5500 \mathrm{~m}^{3}$ day $^{-1}(1000 \mathrm{gpm})$ when the full field area is cultivated with high-value irrigated tomatoes in all years, relative to a value of around $\$ 242,730$ when no groundwater supply is available and significant portions of the field have to be turned over to lower value dryland production in years of lower surface water availability. The potential loss in economic value from reductions in well yields is visualized in Figure 2 $\mathrm{b}$. Importantly, Figure $2 \mathrm{p}$ demonstrates that below well yields (and by implication aquifer saturated thickness) of around $5500 \mathrm{~m}^{3}$ day $^{-1}$ (1000 gpm) the productivity of groundwater decreases significantly due to an inability for stocks to buffer production effectively against stochastic fluctuations in surface 
water deliveries. This result has important implications for groundwater management in conjunctive use systems worldwide, and, in particular, suggests that policies to maintaining well yields will be important to ensure future drought resilience. Further discussion on this topic and the implications of our findings for groundwater management is provided in Section 4.1 .
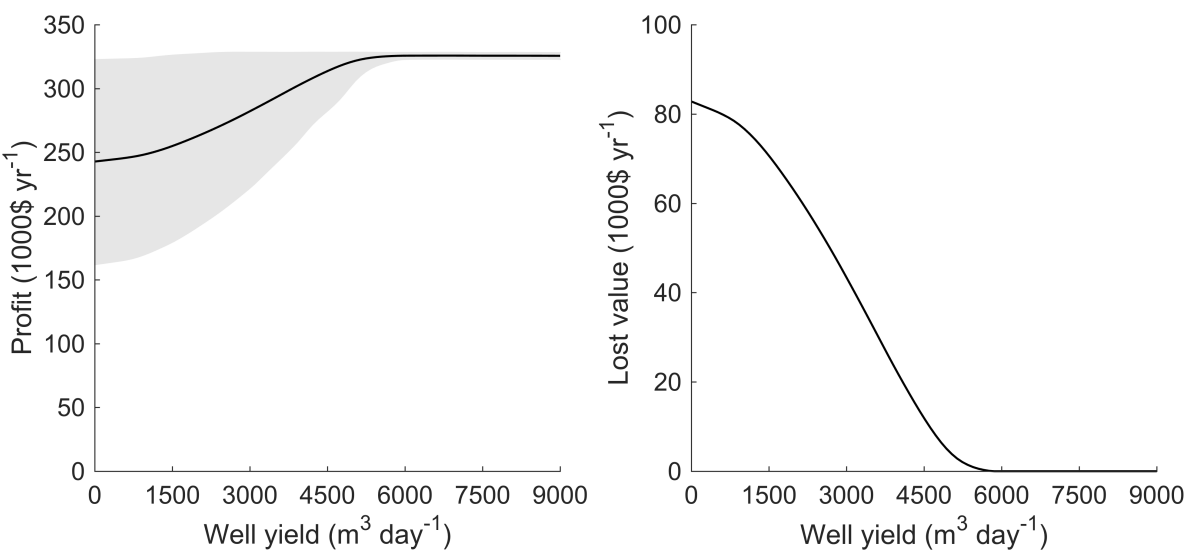

Figure 2: (Left): Response of farm profits (\$) to well yield $\left(\mathrm{m}^{3}\right.$ day $\left.^{-1}\right)$. The solid black line shows the mean response and the grey shaded area represents the bounds of the 10$90^{\text {th }}$ percentiles from the 1000 random draws. (Right): Cumulative loss of profits (\$) from reductions in well yields relative to when groundwater supply is unconstrained. Data in both plots are for furrow irrigated tomatoes, and for surface water deliveries drawn from the moderate distribution given in Table 2 Note that $1 \mathrm{~m}^{3}$ day $^{-1}$ is equivalent to $0.183 \mathrm{gpm}$.

\subsection{Sensitivity to surface water distribution}

The results presented thus far have only considered one possible distribution of surface water deliveries. It is important, therefore, to assess how the value of groundwater, and in particular the sensitivity to changes in well yields, may differ under conditions of higher or lower variability in surface water deliveries.

Figure 3 shows the mean optimal irrigated area and tomato crop yield predicted by our model as a function of well yield for the three surface water distributions described in Table 2, assuming that tomatoes are irrigated using a furrow irrigation system. Figure 3 demonstrates clearly that the sensitivity of 
tomato production to well yields is dependent on the frequency and magnitude of surface water supply deficits. When surface water supply has a high mean and low variability (Low distribution in Table 2) the farmer is able to irrigate close to the full field area (61.5 ha out a maximum of 65 ha) with no groundwater supply, and can fully buffer production for well yields of around $3000 \mathrm{~m}^{3}$ day $^{-1}$ (550 gpm) and above. Contrastingly, when surface water supply has a lower mean and larger variability (High distribution in Table 2), it is only optimal to irrigate 34 ha of land on average (52\% of the field area) without groundwater access. The remaining land area is cultivated with lower value dryland oat hay, with significant impacts on profitability as will be discussed below. Furthermore, a well yield of $5750 \mathrm{~m}^{3}$ day $^{-1}$ or above (1050 gpm) is needed before maximum production levels on both the intensive and extensive margins can be achieved in all years.
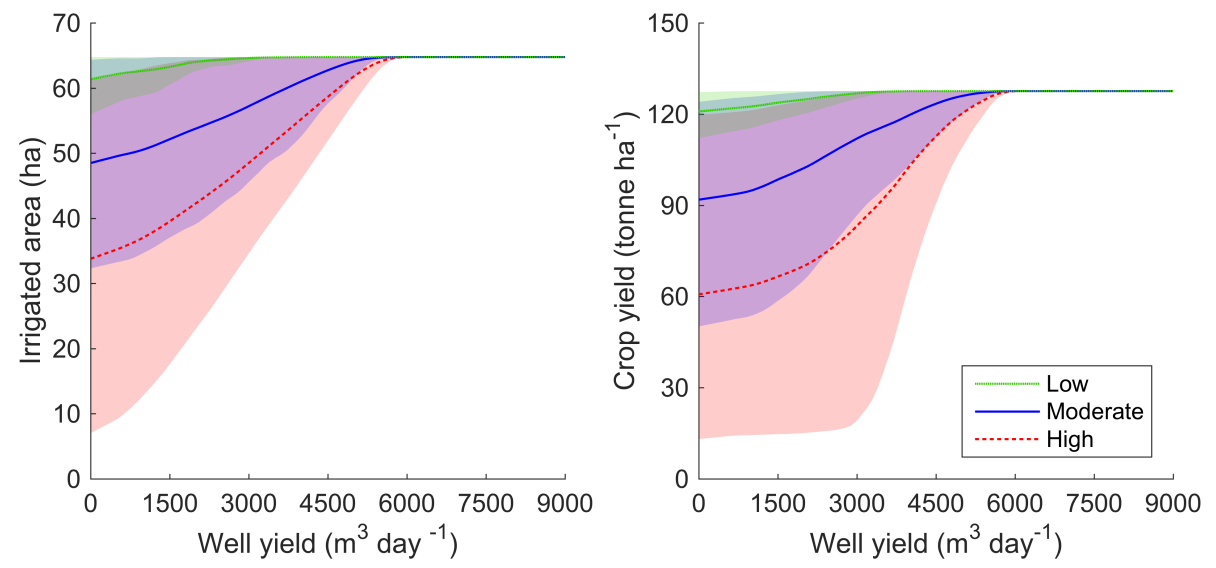

Figure 3: Optimal tomato irrigated area (left) and yields (right) as a function of well yield $\left(\mathrm{m}^{3}\right.$ day $\left.^{-1}\right)$ and three diffrent surface water supply distributions given in Table 2 In each plot, the solid line represents the mean response and the shaded area represents the bounds of the $10-90^{\text {th }}$ percentiles from 1000 random draws. Data in all plots are for furrow irrigated tomatoes. Note that $1 \mathrm{~m}^{3} \mathrm{day}^{-1}$ is equivalent to $0.183 \mathrm{gpm}$.

Figure 4 demonstrates how the differences in irrigation decisions and tomato production outputs shown in Figure 3 translate in to economic losses as well 
yields are reduced. In all cases, below a given well yield, further reductions in well yields have negative economic impacts for farmers, as they are forced to forgoe higher value irrigated tomato production in years when surface water supply is limited. However, the timing and magnitude of economic impacts varies substantially between the three surface water distributions that we have considered in our analyses. For example, reducing well yields to $3000 \mathrm{~m}^{3}$ day ${ }^{-1}$ (550 gpm) leads to losses in production value of $\$ 2,440, \$ 42,945$, and $\$ 83,065$ for the low, moderate, and high variability distributions in Table 2 , respectively. Reducing well yield further to $1500 \mathrm{~m}^{3}$ day $^{-1}$ (275 gpm) enhances these differences, with losses equal to $\$ 14,725, \$ 72,480$, and $\$ 131,950$ for the same three surface water distributions. This result highlights that reductions in well yields caused by aquifer depletion will not impact all farmers equally, with producers with the least secure water rights, or those in areas where well yields are more sensitive to depletion due to heterogeneity in aquifer properties, being most vulnerable to the loss of the intrinsic buffering capacity of groundwater stocks for irrigated crop production.

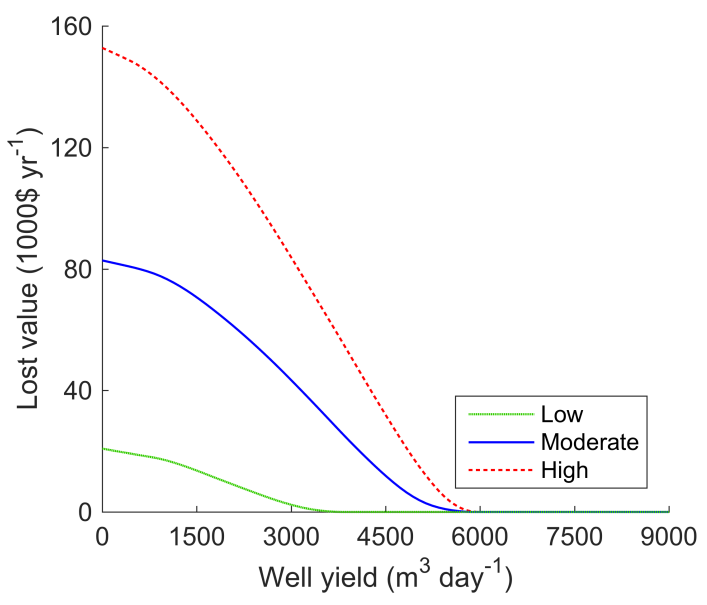

Figure 4: Cumulative loss of profits $(\$)$ from reductions in well yields relative to when groundwater supply is fully unconstrained. Results are shown for the three different surface water supply distributions given in Table 2 All data are for furrow irrigated tomatoes. Note that $1 \mathrm{~m}^{3}$ day $^{-1}$ is equivalent to $0.183 \mathrm{gpm}$. 


\subsection{Benefits of sub-surface drip irrigation}

Farmers faced with increasing and uncertain surface water supply constraints can adapt in a number of ways to minimize risks to crop production when use of groundwater is limited by low well yields. Adaptation options, for example, include drilling deeper wells to improve well yields, purchasing additional surface water supply from other users through water markets, or adopting more efficient irrigation systems. In this section, we assess the implications of the latter type of adaptation, specifically focusing on potential benefits of switching from furrow to sub-surface drip irrigation. As described in Section 2.3, furrow irrigation typically is an inefficient means of applying water as a significant proportion of irrigation often is lost to non-beneficial surface runoff, deep percolation, and evaporation. In contrast, sub-surface drip irrigation is a highly efficient method of applying water directly to the root zone of the crop, and, therefore, is increasingly being adopted by tomato producers in water constrained areas of California. For example, Tindula et al. (2013) show that $63 \%$ of processing tomatoes grown in California are now irrigated using drip technologies (85\% of which is sub-surface) supplied by surface water deliveries, and, in times of water shortage, groundwater pumping

Figure 5 shows how optimal irrigated area and tomato crop yields differ for combinations of surface water distribution (Table 2) and irrigation method (furrow or drip). An important insight from Figure 5 is that both irrigated area and tomato yields under sub-surface drip irrigation are always equal to or higher than under furrow irrigation. Differences between results for furrow and subsurface drip irrigation are most pronounced for the surface water distributions with lower means and higher variability (Moderate and High distributions in Table 2, Panels b and c in Figure 5), and for lower well yields. This reflects the fact that adoption of sub-surface drip irrigation has two main benefits: (1) it reduces total seasonal irrigation requirements, enabling irrigated tomato production areas to be sustained for lower surface water deliveries irrespective of whether a back-up groundwater supply is available; and (2) it minimizes nonbeneficial losses, ensuring that limited instantaneous groundwater supplies can 
be utilized effectively to satisfy peak water requirements of high-value irrigated crops and thereby avoiding the build-up of damaging soil moisture deficits during the growing season.
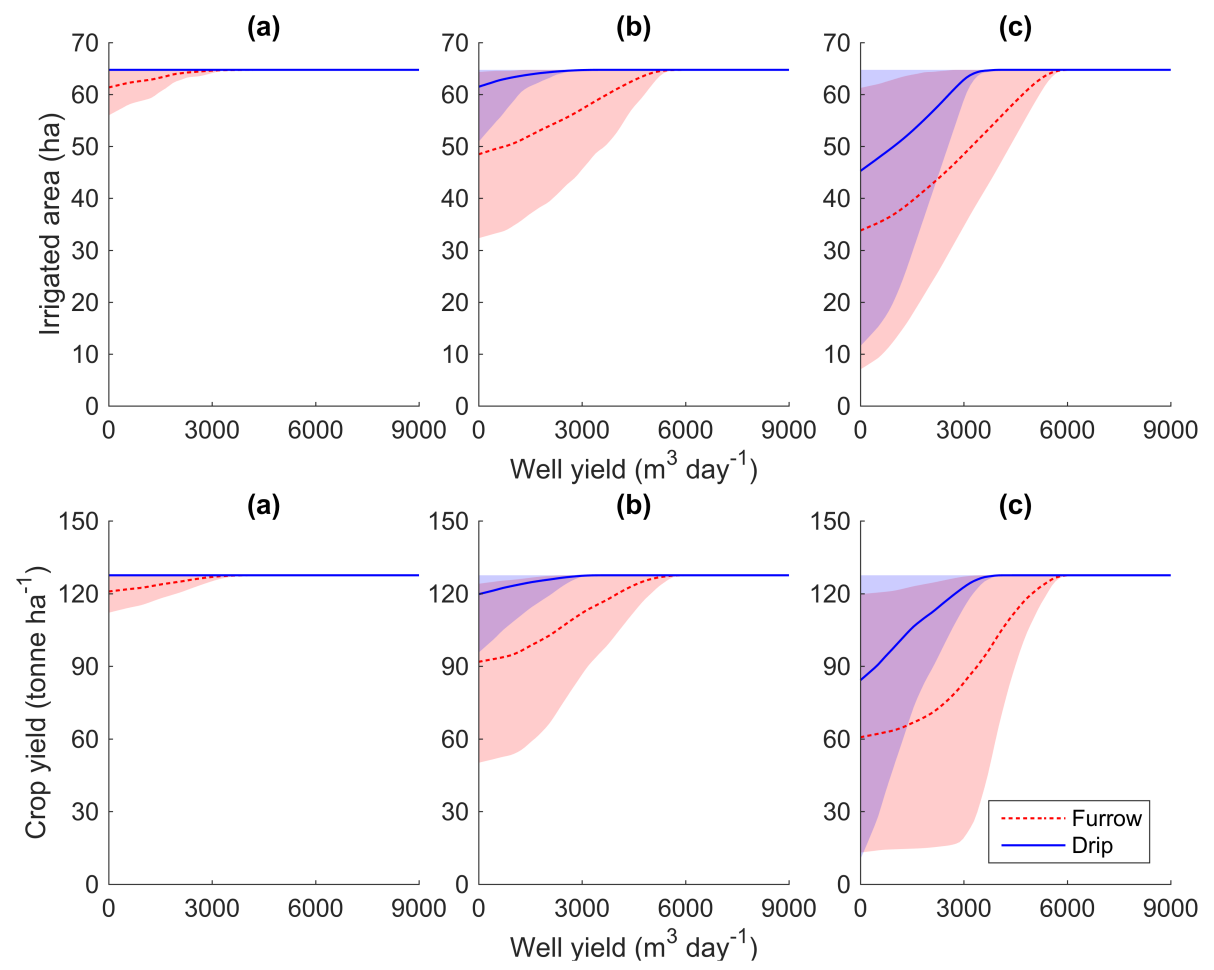

Figure 5: Optimal tomato irrigated area (left) and yields (right) as a function of well yields $\left(\mathrm{m}^{3}\right.$ day $\left.^{-1}\right)$ and two different irrigation methods (furrow and sub-surface drip). Each column relates to results for one of the three surface water supply distributions given in Table 2 (a) Low variability distribution; (b) Moderate variability distribution; (c) High variability distribution. In each plot, the solid line represents the mean response and the shaded area represents the bounds of the $10-90^{\text {th }}$ percentiles from 1000 random draws. Note that $1 \mathrm{~m}^{3} \mathrm{day}^{-1}$ is equivalent to $0.183 \mathrm{gpm}$.

Figure 6 demonstrates the economic impacts of reducing well yields for each combination of surface water distribution and irrigation method. In particular, Figure 6 illustrates two important findings about the interactions between well yield, surface water variability, and irrigation efficiency that emerge from our 
analyses. First, tomato producers with more reliable surface water rights (Figure

6a) may be able to eliminate dependence on groundwater entirely by switching to sub-surface drip irrigation. However, groundwater may still have value for these farmers if they have access to additional land with which to expand production (we assume a land constraint of 65 ha in our analyses). Second, when surface water supply is more variable (Figures 6p and 6r), switching to sub-surface drip will have significant economic benefits, but will not be able to fully offset the losses caused by reductions in well yields and resultant declines in irrigated areas. Indeed, reducing well yields to $1500 \mathrm{~m}^{3}$ day $^{-1}(275 \mathrm{gpm})$ will still lead to economic losses of $\$ 12,255(4 \%)$ and $\$ 78,470$ (20\%) for the moderate and high variability surface water distributions, respectively, in Table 2.

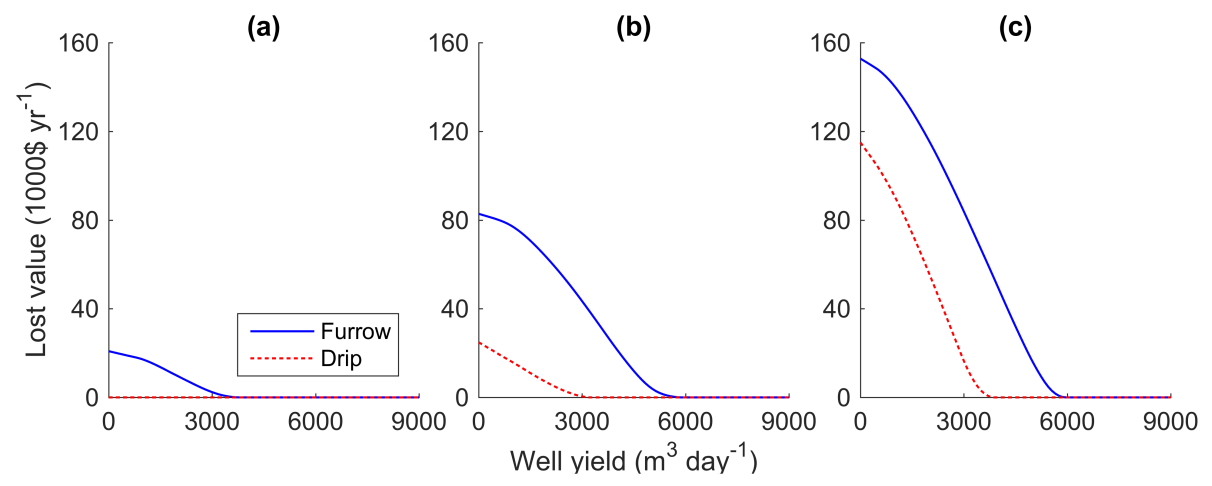

Figure 6: Cumulative loss of profits $(\$)$ from reductions in well yields (relative to when groundwater supply is fully unconstrained) for furrow and sub-surface drip irrigated tomatoes. Each column relates to results for one of the three surface water supply distributions given in Table 2 (a) Low variability distribution; (b) Moderate variability distribution; (c) High variability distribution. Note that $1 \mathrm{~m}^{3} \mathrm{day}^{-1}$ is equivalent to $0.183 \mathrm{gpm}$.

Finally, it is worth noting that adoption of sub-surface drip may not have solely positive impacts, and could also have the unintended consequence of increasing long-term aquifer depletion and, as a result, exacerbating reductions in well yields and loss of irrigated production resilience. Our analysis assumes that the farmer has a land constraint of 160 acres. However, in practice, farmers may be able to use the water savings from switching to more efficient irrigation 
technologies, such as sub-surface drip, to expand irrigated production areas. Previous research has demonstrated that, where this effect occurs, total consumptive water use may increase even though irrigation is used more efficiently on a per-area basis, due to the fact that much of the water "wasted" by inefficient irrigation methods is returned back to groundwater and rivers (Ward and Pulido-Velazquez, 2008, Pfeiffer and Lin, 2014). Asa result, aquifer depletion may be accelerated, further reducing well yields and exacerbating long-term vulnerability to surface water supply variability.

\subsection{Effects of surface water supply uncertainty}

As discussed previously, the analysis and results reported so far have focused on conditions where the farmer knows with certainty each year what surface water allocation they will receive, although the size of that allocation varies inter-annually. However, in some circumstances, for example when water rights are insecure or in heavily over-allocated basins, the farmer may have to decide what land area to plant with irrigated and dryland crops with limited information about how much surface water supply they will receive. This has the potential to create additional volatility in production and profits for farmers with low well yields, who may be unable to buffer planted areas fully in years where surface water allocations are unexpectedly reduced. Figure 7 demonstrates this effect, showing additional reductions in profits as a function of well yield when the farmer only has knowledge of the expected surface water delivery at planting, versus when surface water deliveries are known with certainty in all years. Results in Figure 7 are shown for the three surface water distributions (low, moderate, and high variability Table 2 and two irrigation methods (furrow and sub-surface drip) considered in the previous analyses.

Consistent with the findings presented in previous sections, Figure 7 shows that uncertainty about surface water allocations has different impacts depending on interactions between the degree of variability in surface water supply, the level of on-farm irrigation efficiency, and available groundwater well yield. Producers operating high-efficiency drip irrigation systems with low variability 


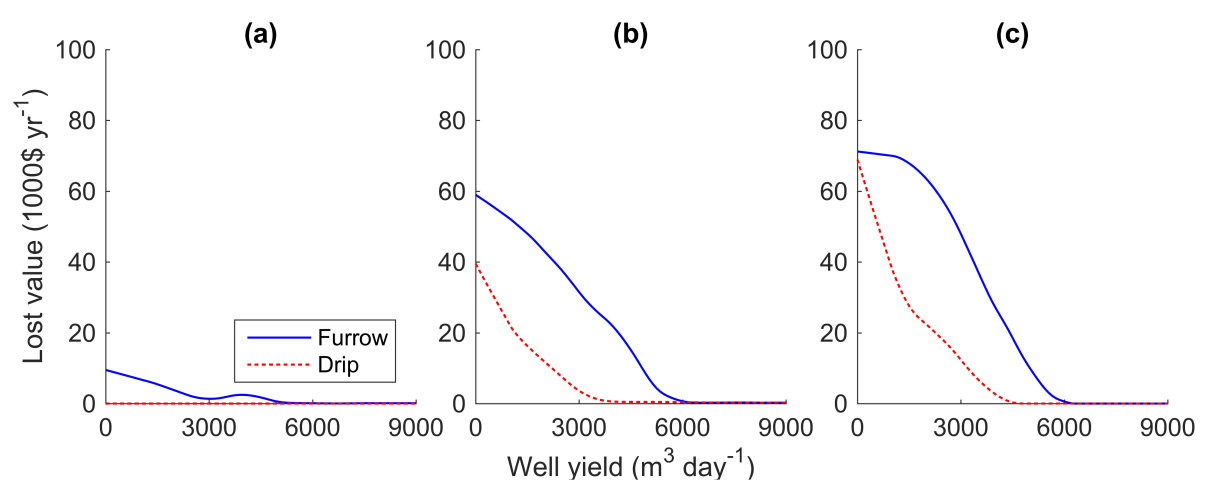

Figure 7: Additional loss of profits (\$) as a function of well yield when surface water supply is uncertain at the time of planting, relative to when surface water allocations are known with certainty in each year. Results are shown for furrow and sub-surface drip irrigation systems. Each column relates to results for one of the three surface water supply distributions given in Table 2 (a) Low variability distribution; (b) Moderate variability distribution; (c) High variability distribution. Note that $1 \mathrm{~m}^{3}$ day $^{-1}$ is equivalent to $0.183 \mathrm{gpm}$.

in surface water deliveries do not rely on groundwater in any year, and, therefore, are unaffected by uncertainty about surface water allocations. Similarly, producers with high well yields are also minimally impacted by this uncertainty, as sufficient groundwater capacity is available to buffer production against unforeseen shortfalls in surface water deliveries.

In contrast, producers with low well yields and more variable surface water supplies (panels b and c in Figure 7) suffer much larger economic losses due to uncertainty about surface water deliveries at planting. For these farmers, restricted well yields limit ability to meet crop water needs in years when surface water supply is lower than expected, leading to reductions in crop yields and, in some cases, even complete crop failure. Indeed, the large reductions in profitability found for producers with low well yields and highly variable surface water supplies (Figure 7p) are driven, in large part, by the fact that the farmer incurs significant losses in years when the irrigated tomato crop fails before harvest due to insufficient water supply. Impacts are most pronounced for those farmers operating inefficient furrow irrigation systems, because, as dis- 
cussed previously, irrigation requirements are greater in these systems due to non-beneficial losses from surface runoff, soil evaporation, and deep percolation.

It is important to highlight that, implicit to this analysis, is the assumption that the farmer does not abandon part of the planted irrigated crop area once it becomes known that surface water supply will be limited. In reality, this may be an optimal adaptation, in particular for farmers with low well yields and highly variable surface water supplies, and could reduce economic losses below the levels predicted in this analysis. Further discussion of the implications of this assumption for our findings, and suggestions for how this simplification could be addressed in future model development is provided in Section 4.2 .

\section{Discussion}

\subsection{Implications for groundwater management in conjunctive use systems}

The results of this study demonstrate that farmers' ability to use groundwater as a reliable and effective buffer against stochastic surface water supply is dependent, in large part, on reliable access to productive boreholes. Aquifer depletion is a critical challenge in many conjunctive use systems, including California's Central Valley, and is being exacerbated by more frequent droughts and growing inter-sectoral competition for water. Our findings indicate that the reductions in well yields caused by depletion are likely to increase significantly agricultural production risk in these systems, and decrease resilience to future climate variability and change if ongoing drawdown of groundwater storage is not addressed.

Our findings contribute valuable knowledge to inform research and policy on groundwater management in conjunctive use systems. Previous efforts to model improved or optimal water resource management in conjunctive use systems (e.g. Noel and Howitt (1982); Provencher and Burt (1993); Pulido-Velazquez et al. (2004); Pulido-Velázquez et al. (2006); Schoups et al. (2006); Harou and Lund (2008); Marques et al. (2009); Davidsen et al. (2016)) have assumed that aquifer depletion will impact economic returns in future periods in two main ways: (1) 
by reducing the stock of groundwater available to buffer production; and (2) by increasing the costs of extracting each additional unit of groundwater. However, existing research and models have not considered the impacts of depletion on the productivity of groundwater stocks in future periods. In this paper, we demonstrate that the biophysical and economic productivity of groundwater is a decreasing, non-linear function of well yield (and, by implication, therefore of saturated thickness). Our analysis is static and, we do not evaluate explicitly the effects of well yield on dynamically optimal groundwater extraction and management. Nevertheless, our results suggest that impacts of depletion on the future productivity of groundwater via reductions in well yield may be an important factor affecting the value of groundwater management decisions.

The effect of well yield on the productivity and buffer value of groundwater also has important implications for the potential distributional effects of groundwater management policies. As an aquifer is depleted, physical reductions in well yields and their impacts on economic returns will not be uniform across farmers. For example, producers with less secure water rights, limited ability to access replacement water sources (e.g. drilling a deeper well), inflexible or water intensive cropping patterns, or those located in less hydrologically productive parts of an aquifer may be disproportionately impacted by aquifer depletion. Previous studies have shown that heterogeneity amongst farmers in terms of other factors, such as farm size, technology, or land productivity, will lead to winners and losers from groundwater management Athanassoglou et al., 2012, Saak and Peterson, 2012, Guilfoos et al. 2016). To date, however, no study has considered well yield and its effects on groundwater productivity to be an important source of heterogeneity. A valuable area for future work would be to evaluate the welfare effects of policies that target water use reductions in space and time to minimize negative impacts of well yield reductions. Water markets, for example, have be suggested as solutions to reduce streamflow depletion impacts from groundwater pumping (Thompson et al., 2009, Palazzo and Brozović, 2014, Wheeler et al., 2016), and, in principle, could also be used to encourage conservation of the productivity and buffer value of groundwater 
in conjunctive use systems.

Finally, our results demonstrate some of the limitations of current methods used to define and characterize the buffer value of groundwater. Existing economic theory (Tsur and Graham-Tomasi, 1991, Gemma and Tsur, 2007, Tsur 2015 ) distinguishes between the stabilization and augmentation value generated by access to groundwater in conjunctive use systems. This distinction is made possible because such studies assume that groundwater supply is unconstrained, and that the intraseasonal distribution of water availability has limited effects on revenues. This assumption is only valid, however, for large well yields that do not impose meaningful constraints on intraseasonal irrigation scheduling. As well yields are reduced, our findings show that the seasonal model of groundwater's buffer value breaks down for two important reasons. First, when well yields are highly constrained, groundwater pumping may be insufficient to stabilize fully water supply at the mean even if pumps are run 24/7. Second, identical amounts of seasonal irrigation may produce different crop yields and profits when there are intraseasonal constraints on groundwater-fed irrigation. Intraseasonal restrictions on how farmers with low well yields are able to apply groundwater fundamentally alter the crop-water production function (Foster et al. 2014), such that, for example, applying $600 \mathrm{~mm}$ of surface water with no constraints will produce a higher crop yield than applying $300 \mathrm{~mm}$ each of surface water and groundwater, the latter with significant restrictions on how and when irrigation can be applied. Our model demonstrates that groundwater and surface water may not be perfect substitutes in a depleting aquifer setting due to the constraints imposed by low well yields, and highlights the need to consider the temporal distribution of water use within a season when estimating the value of groundwater as a buffer against surface water variability.

\subsection{Model assumptions and simplifications}

Having discussed the key contributions and policy implications of our analyses, it is important to discuss some assumptions made in our modeling framework and highlight potential avenues for future research and model development. 
First, in this study we analyze the effects of declining well yields for only one irrigated crop (tomatoes), and we assume that any non-irrigated land generates a fixed per-acre return consistent with typical returns reported for dryland oat hay production in the region. In reality, farmers in California, and indeed other conjunctive use systems, grow a diverse range of crop types. The exact economic impacts of declining well yields therefore will vary depending on the sensitivity of both the irrigated crop choice to changes in instantaneous groundwater supply constraints, and the relative value of alternative production choices made on the portion of the land that is not irrigated. We have repeated our analyses for two other annual crop types, corn and cotton (results are no reported in this paper due to space limitations), that are grown in California's Central Valley. We find that, while well yield is always a significant determinant of the value of groundwater, the threshold capacity needed to achieve full production is lower due to the greater drought tolerance of these crops (in particular cotton) relative to tomatoes. Other crops, however, may have even greater sensitivity to reduced well yields than tomatoes. Perennial tree crops, for example, are widely cultivated in California, and may be more vulnerable to water supply deficits as high levels of water stress can degrade crop yield potential, and therefore revenues, for all future years in the crop's life cycle Planted areas of perennial crops also can't be adjusted easily in the same way as for annual crops, due to the large investment costs at planting and because limited harvestable yield typically is produced in an initial multi-year period of development. An interesting extension of our analysis would be to quantify the value of maintaining well yields for perennial crop production, and, in particular, to assess how this value varies over the multi-year life cycle of a crop under conditions of stochastic surface water supply. A related analysis is performed by (Feinerman and Tsur. 2014). However, their research focuses on recycled water as a back-up source of supply and, therefore, does not address the implications of aquifer depletion for drought risk in high-value perennial crop production.

In our analysis, we make the implicit assumption that the only back-up source of water supply is groundwater. In practice, in years when surface wa- 
ter deliveries are reduced, the presence of informal or formal water markets may provide farmers with a means of acquiring additional surface water above their allocation, albeit typically at higher cost than groundwater (Howitt et al. 2015). For producers of lower value crops, such as corn or cotton, it would be unlikely to be cost effective to purchase additional surface water supply in order to support low value production areas. However, producers of lower value crops, in particular those with higher well yields, could benefit financially from selling their available surface water allocation to producers of higher value crops, such as tomatoes and perennial tree crops, for whom the additional costs of buying scarce water through a market are justified by the benefits obtained from maintaining high-value irrigated production areas and avoiding risks of crop failure. A water market therefore could play an important role in minimizing the total economic costs of low well yields in years where surface water allocations are constrained (e.g. during drought events). However, it is also important to note that, in this situation, producers of lower value crops may increase their groundwater consumption, with potential implications for future well yields and resilience to surface water supply shortfalls. Alternatively, in very thick aquifers such as the Central Valley, farmers' may also choose to drill deeper wells to increase well yields and maintain high levels of production. For example, during the recent drought in California, there has been a large spike in irrigation well drilling in response to falling water tables and declining well yields. Costs of well drilling are high (often several hundred thousand dollars), however, and therefore may only be a financially viable adaptation for farmers' growing higher value crops. Furthermore, the costs of well drilling are also an additional economic impact of aquifer depletion that typically is not considered in economic analysis of groundwater management. An interesting area for future research therefore would be to explore to what extent welfare gains from groundwater management are enhanced when considering avoided future well drilling costs due to aquifer depletion.

An additional simplification of our analyses is that we assume, for any individual daily irrigation event, that surface water and groundwater sources can't 
be mixed. Consequently, we do not consider the possibility that farmers' could combine available surface water and groundwater supplies to maximise instantaneous irrigation rates across the entire growing season. It is possible that blending the two water sources may be an economically optimal strategy for some farmers' with low well yields, and could limit some of the reductions in crop production and profits caused by instantaneous groundwater pumping constraints. However, in reality, farmers must balance these potential benefits from reduced production risk with the higher energy costs associated with pumping groundwater often from significant depths. Furthermore, such a blending approach may also carry risks depending on the structure and operation of surface water rights and allocations. For example, a farmer may be unable to use part of their allocation later in the growing season if pumping is curtailed prematurely, or if the system is over-allocated and available storage is diverted by others users earlier in the season. Future work should seek to expand the model developed in this paper to assess the potential benefits of mixing of surface and groundwater sources for farmers with low well yields, considering differences in costs of surface versus groundwater resources and potential uncertainty about the window of time that it will be physically or institutionally possible to divert surface water for irrigation. Analysis could also consider instantaneous limits to surface water abstractions, for example due to limited flow in canals, which have been neglected in this study, but could interact with constraints imposed by low well yields to exacerbate crop production risks.

Finally, a further important area for future work will be to explore in greater detail how uncertainty about surface water deliveries at planting, in particular for farmers with less secure surface water rights, affects the costs associated with declining well yields. Our analysis has shown that producers who have limited knowledge about surface water deliveries each year suffer much greater losses of production and profits than those farmers who know with certainty how much surface water they will receive. This observation is comparable to the findings presented by García-Vila and Fereres (2012), who showed that the communication date of water restrictions in a surface water irrigation system in Spain 
has large impacts on farmers planting decisions and resultant profits. Nevertheless, it is important to highlight that the two cases we examine represent the extreme bounds on farmers potential knowledge about surface water deliveries. In reality, actual information available to farmers will likely fall between these extremes, and some degree of pre-season adaptation through adjustments to irrigated areas or crop choices will be possible. Furthermore, we do not consider the potential for farmers to abandon planted land area part way through the season when surface water deliveries are uncertain. In practice, this may be an optimal adaptation for some farmers, in particular in years where deliveries are unexpectedly low and there is a need to prioritize limited water supply to avoid risks of total crop failure. Future work should seek to extend our analysis to consider under what conditions partial abandonment of crops is an optimal decision for farmers with low well yields, and to what extent such practices have occurred during recent periods of extreme water shortages in California and other conjunctive use systems.

\section{Conclusions}

In this paper, we advance understanding of the economic value of groundwater in conjunctive use systems by quantifying the impacts of low well yields on the productivity of groundwater as a buffer against stochastic surface water supply. Through a case study of tomato production in California's Central Valley, we show that groundwater should not be considered an unconstrained substitute for surface water when aquifer depletion has led to reductions in well yields. Specifically, we find that farmers' with limited well yields face increased production risk and profit volatility because instantaneous groundwater application rates are insufficient to satisfy crop water demands during drought years when surface water allocations are low, forcing farmers' to reduce irrigated area and forgo potential production in these years. Previous research has assumed that externalities from groundwater pumping relate to reductions in the availability and increases in the costs of groundwater in future periods. However, our 
findings highlight the importance of also considering the impacts of depletion on the future economic productivity of groundwater stocks.

Our findings have important implications for groundwater management in conjunctive use systems worldwide. Climate change, coupled with growing intersectoral competition for water, is expected to exacerbate variability in surface water supply for irrigation in future years, and, most importantly, lead to an increase in the frequency and intensity of surface water supply restrictions. These changes are likely to result in greater reliance on groundwater resources, which, in many conjunctive use systems, already are being chronically depleted. We suggest that limiting future reductions in well yields will be important in order to maintain capacity for groundwater stocks to buffer effectively crop production against increasing variability in surface water flows. It is beyond the scope of this study to analyze which types of policies will be most effective at achieving this goal, or if such policies would be economically or institutionally practical. Future work could explore this question, and, in particular, evaluate the potential benefits of policies to target reductions in groundwater pumping spatially and temporally in ways that minimize future externalities on irrigated agriculture from declining well yields and diminished productivity of groundwater resources.

\section{Acknowledgments}

This research was funded in part by a NOAA/ECS Federal grant award entitled 'Groundwater management in a conjunctive use system with managed flows for protected fish species' and by USDA NIFA Award number 2012-6700323227

\section{References}

Aeschbach-Hertig, W., Gleeson, T., 2012. Regional strategies for the accelerating global problem of groundwater depletion. Nature Geoscience 5, 853-861. doi $10.1038 /$ ngeo 1617 
Arnold, B.J., Upadhyaya, S.K., Roach, J., Kanannavar, P.S., Putnam, D.H., 2014. Water advance model and sensor system can reduce tail runoff in irrigated alfalfa fields. California Agriculture 68, 82-88.

Athanassoglou, S., Sheriff, G., Siegfried, T., Huh, W.T., 2012. Optimal mechanisms for heterogeneous multi-cell aquifers. Environmental and Resource Economics 52, 265-291. doi:10.1007/s10640-011-9528-0

Bali, K.M., Grismer, M.E., Tod, I.C., 2001. Reduced-runoff irrigation of alfalfa in Imperial Valley, California. Journal of Irrigation and Drainage Engineering 127, 123-130. doi 10.1061/(ASCE) 0733-9437(2001) 127:3(123)

Davidsen, C., Liu, S., Mo, X., Rosbjerg, D., Bauer-Gottwein, P., 2016. The cost of ending groundwater overdraft on the North China Plain. Hydrology and Earth System Sciences 20, 771-785. doi:10.5194/hess-20-771-2016.

Elliott, J., Deryng, D., Müller, C., Frieler, K., Konzmann, M., Gerten, D., Glotter, M., Flörke, M., Wada, Y., Best, N., et al., 2014. Constraints and potentials of future irrigation water availability on agricultural production under climate change. Proceedings of the National Academy of Sciences 111, 3239-3244. doi:10.1073/pnas.1222474110.

Famiglietti, J.S., Lo, M., Ho, S.L., Bethune, J., Anderson, K.J., Syed, T.H., Swenson, S.C., De Linage, C.R., Rodell, M., 2011. Satellites measure recent rates of groundwater depletion in California's Central Valley. Geophysical Research Letters 38, L03403. doi:10.1029/2010GL046442.

Faunt, C.C., Hanson, R.T., Belitz, K., 2009. Groundwater availability of the Central Valley Aquifer. Professional Paper 1766. United States Geological Survey, Reston, VA, USA.

Faunt, C.C., Sneed, M., Traum, J., Brandt, J.T., 2016. Water availability and land subsidence in the Central Valley, California, USA. Hydrogeology Journal 24, 675-684. doi $10.1007 / \mathrm{s} 10040-015-1339-\mathrm{x}$. 
Feinerman, E., Tsur, Y., 2014. Perennial crops under stochastic water supply.

Agricultural Economics 45, 757-766. doi 10.1111/agec.12120

Foster, S., van Steenbergen, F., 2011. Conjunctive groundwater use: a 'lost opportunity' for water management in the developing world? Hydrogeology Journal 19, 959-962. doi:10.1007/s10040-011-0734-1.

Foster, T., Brozović, N., Butler, A., Neale, C., Raes, D., Steduto, P., Fereres, E., Hsiao, T., 2017. AquaCrop-OS: An open source version of FAO's crop water productivity model. Agricultural Water Management 181, 18-22. doi 10 . 1016/j.agwat.2016.11.015.

Foster, T., Brozović, N., Butler, A.P., 2014. Modeling irrigation behavior in groundwater systems. Water Resources Research 50, 6370-6389. doi 10 . 1002/2014WR015620.

Foster, T., Brozović, N., Butler, A.P., 2015a. Analysis of the impacts of well yield and groundwater depth on irrigated agriculture. Journal of Hydrology 523, 86-96. doi $10.1016 / j \cdot j h y d r o l .2015 .01 .032$.

Foster, T., Brozović, N., Butler, A.P., 2015b. Why well yield matters for managing agricultural drought risk. Weather and Climate Extremes 10, 11-19. doi: $10.1016 / \mathrm{j}$. wace.2015.07.003.

de Frutos Cachorro, J., Erdlenbruch, K., Tidball, M., 2014. Optimal adaptation strategies to face shocks on groundwater resources. Journal of Economic Dynamics and Control 40, 134-153. doi $10.1016 / j \cdot j$ edc.2014.01.005.

García-Vila, M., Fereres, E., 2012. Combining the simulation crop model aquacrop with an economic model for the optimization of irrigation management at farm level. European Journal of Agronomy 36, 21-31. doi 10 . $1016 / j . e j a .2011 .08 .003$.

Gemma, M., Tsur, Y., 2007. The stabilization value of groundwater and conjunctive water management under uncertainty. Applied Economic Perspectives and Policy 29, 540-548. doi:10.1111/j.1467-9353.2007.00366.x. 
Grantham, T.E., Mezzatesta, M., Newburn, D.A., Merenlender, A.M., 2014. Evaluating tradeoffs between environmental flow protections and agricultural

water security. River Research and Applications 30, 315-328. doi 10.1002/ rra.2637

Grantham, T.E., Viers, J.H., 2014. 100 years of California's water rights system: patterns, trends and uncertainty. Environmental Research Letters 9, 8401284021. doi:10.1088/1748-9326/9/8/084012.

Guilfoos, T., Khanna, N., Peterson, J.M., 2016. Efficincy of viable groundwater management policies. Land Economics 92, 618-640. doi:10.3368/le.92.4. 618.

Harou, J.J., Lund, J.R., 2008. Ending groundwater overdraft in hydrologicq economic systems. Hydrogeology Journal 16, 1039-1055. doi 10.1007/ s10040-008-0300-7.

Hartz, T. Miyao, G., Mickler, J., Lestrange, M., Stoddard, S., Nunez, J., Aegerter, B., 2008. Processing tomato production in California. Publication no. 7228. University of California, Davis, California, USA.

Hecox, G.R., Macfarlane, P.A., Wilson, B.B., 2002. Calculation of yield for High Plains wells: Relationship between saturated thickness and well yield. Report No.2002-25C. Kansas Geological Survey, Lawrence, KS, USA.

Howitt, R.E., MacEwan, D., Medellín-Azuara, J., Lund, J.R., Sumner, D., 2015. Economic analysis of the 2015 drought for California agriculture. UC Davis Center for Watershed Sciences, Davis, California, USA.

Howitt, R.E., Medellín-Azuara, J., Lund, J.R., Sumner, D., 2014. Economic analysis of the 2014 drought for California agriculture. UC Davis Center for Watershed Sciences, Davis, California, USA.

Katerji, N., Campi, P., Mastrorilli, M., 2013. Productivity, evapotranspiration, and water use efficiency of corn and tomato crops simulated by AquaCrop 
under contrasting water stress conditions in the Mediterranean region. Agricultural Water Management 130, 14-26. doi:10.1016/j.agwat.2013.08.005

Knapp, K.C., Olson, L.J., 1995. The economics of conjunctive groundwater management with stochastic surface supplies. Journal of Environmental Economics and Management 28, 340-356. doi 10.1006/jeem.1995.1022.

Linker, R., Ioslovich, I., Sylaios, G., Plauborg, F., Battilani, A., 2016. Optimal model-based deficit irrigation scheduling using AquaCrop: A simulation study with cotton, potato and tomato. Agricultural Water Management 163, 236243. doi $10.1016 / \mathrm{j}$.agwat.2015.09.011

Long, R., Munier, D., Klonsky, K.M., De Moura, R.L., 2012. Sample costs to produce oat hay. University of California Cooperative Extension, Davis, California, USA.

Marques, G.F., Lund, J.R., Howitt, R.E., 2009. Modeling conjunctive use operations and farm decisions with two-stage stochastic quadratic programming. Journal of Water Resources Planning and Management 136, 386-394. doi:10.1061/(ASCE)WR.1943-5452.0000045.

Medellín-Azuara, J., MacEwan, D., Howitt, R.E., Koruakos, G., Dogrul, E.C., Brush, C.F., Kadir, T.N., Harter, T., Melton, F., Lund, J.R., 2015. Hydro-economic analysis of groundwater pumping for irrigated agriculture in California's Central Valley, USA. Hydrogeology Journal 23, 1205-1216. doi:10.1007/s10040-015-1283-9.

Mehta, V.K., Haden, V.R., Joyce, B.A., Purkey, D.R., Jackson, L.E., 2013. Irrigation demand and supply, given projections of climate and land-use change, in Yolo County, California. Agricultural Water Management 117, 70-82. doi: $10.1016 /$ j. agwat.2012.10.021.

Miyao, G., Aegerter, B., Klonsky, K., Stewart, D., 2014a. Sample costs to produce processing tomatoes: furrow irrigated. University of California Cooperative Extension, Davis, California, USA. 
Miyao, G., Aegerter, B., Klonsky, K., Stewart, D., 2014b. Sample costs to produce processing tomatoes: sub-surface drip irrigated. University of California Cooperative Extension, Davis, California, USA.

Noel, J.E., Howitt, R.E., 1982. Conjunctive multibasin management: an optimal control approach. Water Resources Research 18, 753-763. doi 10.1029/ WR018i004p00753

OECD, 2015. Drying Wells, Rising Stakes. Towards Sustainable Agricultural Groundwater Use. OECD, Paris, France.

Palanisami, K., Giordano, M., Kakumanu, K.R., Ranganathan, C.R., 2012. The stabilization value of groundwater: evidence from Indian tank irrigation systems. Hydrogeology Journal 20, 933-941. doi 10.1007/s10040-011-0793-3.

Palazzo, A., Brozović, N., 2014. The role of groundwater trading in spatial water management. Agricultural Water Management 145, 40-50. doi 10.1016/j. agwat.2014.03.004.

Pfeiffer, L., Lin, C.Y., 2014. Does efficient irrigation technology lead to reduced groundwater extraction? Empirical evidence. Journal of Environmental Economics and Management 67, 189-208. doi:10.1016/j.jeem.2013.12.002.

Provencher, B., Burt, O., 1993. The externalities associated with the common property exploitation of groundwater. Journal of Environmental Economics and Management 24, 139-158. doi 10.1006/jeem.1993.1010.

Provencher, B., Burt, O., 1994. Approximating the optimal groundwater pumping policy in a multiaquifer stochastic conjunctive use setting. Water Resources Research 30, 833-843. doi:10.1029/93WR02683.

Pulido-Velázquez, M., Andreu, J., Sahuquillo, A., 2006. Economic optimization of conjunctive use of surface water and groundwater at the basin scale. Journal of Water Resources Planning and Management 132, 454-467. doi 10.1061/ (ASCE) 0733-9496(2006)132:6(454). 
Pulido-Velazquez, M., Jenkins, M.W., Lund, J.R., 2004. Economic values for conjunctive use and water banking in southern California. Water Resources Research 40, W03401. doi:10.1029/2003WR002626

Raes, D., Steduto, P., Hsiao, T.C., Fereres, E., 2016. AquaCrop Version 5.0 Reference Manual. Food and Agriculture Organization of the United Nations, Rome, Italy.

Ranganathan, C.R., Palanisami, K., 2004. Modeling economics of conjunctive surface and groundwater irrigation systems. Irrigation and Drainage Systems 18, 127-143. doi 10.1023/B: IRRI.0000040251.52864.7e.

Reichard, E.G., Li, Z., Hermans, C., 2010. Emergency use of groundwater as a backup supply: Quantifying hydraulic impacts and economic benefits. Water Resources Research 46, W09524. doi:10.1029/2009WR008208.

Richey, A.S., Thomas, B.F., Lo, M.H., Reager, J.T., Famiglietti, J.S., Voss, K., Swenson, S., Rodell, M., 2015. Quantifying renewable groundwater stress with GRACE. Water Resources Research 51, 5217-5238. doi 10.1002/ 2015WR017349.

Rinaldi, M., Garofalo, P., Rubino, P., Steduto, P., 2011. Processing tomatoes under different irrigation regimes in Southern Italy: agronomic and economic assessments in a simulation case study. Journal of Agrometeorology 3, 39-56.

Ritchel, M., 2015. California farmers dig deeper for water, sipping their neighbors dry. New York Times URL: https:

ㅁ]/WwW.nytimes.com/2015/06/07/business/energy-environment/

california-farmers-dig-deeper-for-water-sipping-their-neighbors-dry. html?_r=0.

Saak, A.E., Peterson, J.M., 2012. Groundwater pumping by heterogeneous users. Hydrogeology Journal 20, 835-849. doi:10.1007/s10040-012-0854-2.

Scanlon, B.R., Faunt, C.C., Longuevergne, L., Reedy, R.C., Alley, W.M., McGuire, V.L., McMahon, P.B., 2012. Groundwater depletion and sustain- 
ability of irrigation in the US High Plains and Central Valley. Proceedings

of the National Academy of Sciences 109, 9320-9325. doi:10.1073/pnas. 1200311109

Scanlon, B.R., Reedy, R.C., Faunt, C.C., Pool, D., Uhlman, K., 2016. Enhancing drought resilience with conjunctive use and managed aquifer recharge in California and Arizona. Environmental Research Letters 11, 035013. doi:10.1088/1748-9326/11/4/049501.

Schewe, J., Heinke, J., Gerten, D., Haddeland, I., Arnell, N.W., Clark, D.B., Dankers, R., Eisner, S., Fekete, B.M., Colón-González, F.J., et al., 2014. Multimodel assessment of water scarcity under climate change. Proceedings of the National Academy of Sciences 111, 3245-3250. doi:10.1073/pnas. 1222460110 .

Schoups, G., Addams, C.L., Minjares, J.L., Gorelick, S.M., 2006. Sustainable conjunctive water management in irrigated agriculture: Model formulation and application to the Yaqui Valley, Mexico. Water Resources Research 42, W10417. doi:10.1029/2006WR004922.

Seager, R., Ting, M., Li, C., Naik, N., Cook, B., Nakamura, J., Liu, H., 2013. Projections of declining surface-water availability for the southwestern United States. Nature Climate Change 3, 482-486. doi 10.1038/nclimate1787.

Singh, A., 2014. Conjunctive use of water resources for sustainable irrigated agriculture. Journal of Hydrology 519, 1688-1697. doi:10.1016/j.jhydrol. 2014.09.049.

Steduto, P., Hsiao, T.C., Raes, D., Fereres, E., 2009. AquaCrop - The FAO crop model to simulate yield response to water: I. concepts and underlying principles. Agronomy Journal 101, 426-437. doi 10.2134/agronj2008.0139s.

Taylor, R.G., Scanlon, B., Döll, P., Rodell, M., Van Beek, R., Wada, Y., Longuevergne, L., Leblanc, M., Famiglietti, J.S., Edmunds, M., et al., 2013. 
Ground water and climate change. Nature Climate Change 3, 322-329. doi:10.1038/nclimate1744

Thompson, C.L., Supalla, R.J., Martin, D.L., McMullen, B.P., 2009. Evidence supporting cap and trade as a groundwater policy option for reducing irrigation consumptive use1. Journal of the American Water Resources Association 45, 1508-1518. doi:10.1111/j.1752-1688.2009.00384.x.

Tsur, Y., 1990. The stabilization role of groundwater when surface water supplies are uncertain: The implications for groundwater development. Water Resources Research 26, 811-818. doi:10.1029/WR026i005p00811.

Tsur, Y., 1997. The economics of conjunctive ground and surface water, in: Parker, D., Tsur, Y. (Eds.), Decentralization and coordination of water resource management. Kulwer, London, UK.

Tsur, Y., 2015. Conjunctive management of water resources in agriculture, in: Dinar, A., Schwabe, K. (Eds.), Handbook of Water Economics. Edward Elgar Publishing, Cheltenham, UK.

Tsur, Y., Graham-Tomasi, T., 1991. The buffer value of groundwater with stochastic surface water supplies. Journal of Environmental Economics and Management 21, 201-224. doi 10.1016/0095-0696(91)90027-G.

U.S. Bureau of Reclamation, 2016. Summary of water supply allocations.

URL: https://www.usbr.gov/mp/cvo/vungvari/water_allocations_ historical.pdf

Veshkin, A., 2015. Dry wells plague California as drought has water tables plunging. Bloomberg URL:

https://www.bloomberg.com/news/articles/2015-04-17/ california-plagued-by-dry-wells-as-drought-makes-water-elusive.

Ward, F.A., Pulido-Velazquez, M., 2008. Water conservation in irrigation can increase water use. Proceedings of the National Academy of Sciences 105, 18215-18220. doi $10.1073 /$ pnas.0805554105. 
970 Wheeler, S.A., Schoengold, K., Bjornlund, H., 2016. Lessons to be learned 971 from groundwater trading in australia and the united states, in: Jakeman, $972 \quad$ A.J., Barreteau, O., Hunt, R.J., Rinaudo, J.D., Ross, A. (Eds.), Integrated Groundwater Management. Springer, pp. 493-517. 